\title{
Consequences of experimental addition of fresh, aromatic plants into nests of blue tits (Cyanistes caeruleus) on the physiological condition of nestlings
}

\author{
Michał Glądalski ${ }^{1}$ (D) Mirosława Bańbura ${ }^{2} \cdot$ Adam Kaliński $^{1} \cdot$ Marcin Markowski $^{1}$ - Joanna Skwarska ${ }^{1}$. \\ Jarosław Wawrzyniak ${ }^{1}$. Piotr Zieliński ${ }^{3}$. Jerzy Bańbura ${ }^{1}$
}

Received: 17 October 2019 / Revised: 27 January 2020 / Accepted: 31 January 2020 / Published online: 12 February 2020

(C) The Author(s) 2020

\begin{abstract}
The blue tit (Cyanistes caeruleus) is one of a few known passerine birds that incorporate fresh fragments of aromatic plants in their nest during the nesting period. In this study, we experimentally tested whether aromatic plants in blue tit nests affect physiological condition of nestlings as indicated by hemoglobin and glucose in the blood. Nestlings in nests supplemented with fresh, aromatic plants had elevated blood hemoglobin, and therefore improved physiological condition, as compared with control nestlings. There was no difference between nestlings in two contrasting habitats (urban parkland and forest). Although mean levels of blood glucose did not differ between treatment and control nestlings, the blood of forest nestlings contained more glucose than the blood of parkland nestlings, which indicates poorer health for forest nestlings. In general, knowledge of the effects of incorporating fresh green, aromatic plant material into avian nests on physiological condition of nestlings is still fragmentary and more experimental studies are needed.
\end{abstract}

\section{Significance statement}

The blue tit is one of a few known passerine birds that incorporate fresh fragments of aromatic plants in their nest during the nesting period. Little is known about the impact of this material on nestling body condition, and there is a need to understand this behavior and its effects. We tested whether nestlings in nests supplemented with fresh, aromatic plants improved their physiological condition in comparison with control nestlings. The experiment showed that nestlings from supplemented nests improved their physiological condition by exhibiting elevated hemoglobin.

Keywords Aromatic plants $\cdot$ Body condition $\cdot$ Hygienic behavior $\cdot$ Nest $\cdot$ Physiological condition $\cdot$ Parasite pressure

Communicated by S. Pruett-Jones

Michał Glądalski

michal.gladalski@biol.uni.lodz.pl

1 Department of Experimental Zoology and Evolutionary Biology, Faculty of Biology and Environmental Protection, University of Łódź, Banacha 12/16, 90-237 Łódź, Poland

2 Museum of Natural History, Faculty of Biology and Environmental Protection, University of Łódź, Kilińskiego 101, 90-011 Łódź, Poland

3 Department of Ecology and Vertebrate Zoology, Faculty of Biology and Environmental Protection, University of Łódź, Banacha 12/16, 90-237 Łódź, Poland

\section{Introduction}

A bird's nest is a multi-functional structure that provides a specific environment for eggs, nestlings, and parents (Collias and Collias 1984; Heenan 2013; Mainwaring et al. 2014; Mainwaring 2016, 2017; Glądalski et al. 2016a). It assists microclimate maintenance, contributes to protection from predators, and helps to support the position of eggs during incubation (Deeming 2011; Álvarez et al. 2013; Lambrechts et al. 2014, 2017; Maziarz et al. 2017; Deeming and Campion 2018; Deeming et al. 2019). On the other hand, nests can also be occupied by invertebrates and microbes (West et al. 2015). Nests of secondary hole-nesting species, like tits (family: Paridae), are protected, have a warm and moist environment, and often contain remains of nestling food. This 
makes them an appropriate breeding habitat for a large diversity of invertebrate parasites and other opportunistic species.

The vast majority of ectoparasites found in avian nests are arthropods, particularly insects and arachnids that feed on blood, skin scrapings, excrement, feathers, and dead nestlings (Hurtrez-Boussès et al. 1998; Bańbura et al. 2001; Heylen et al. 2013; López-Rull and Macías Garcia 2015; Reynolds et al. 2016). Besides being suitable for arthropods, nests can be ideal environments for microbial growth (West et al. 2015). In a study using culture-based methods, 13 fungal and 32 bacterial species were found from the nests of two closely related tit species, the great tit (Parus major) and the blue tit (Cyanistes caeruleus) (Goodenough and Stallwood 2010). Some of those bacterial species were found exclusively in the nests of one species, but not the other, which may suggest specialization (Goodenough and Stallwood 2010).

In general, parasites have the potential to affect the life history of their hosts and can act as a strong selective pressure (Hamilton and Zuk 1982). Nest ectoparasites are harmful to their hosts due to draining resources, which may cause damage that can be subtle, severe, or sometimes lethal (West et al. 2015). Birds often possess behavioral and physiological mechanisms to either fight or repel parasites. Among such mechanisms there are hygienic behaviors such as preening, sunbathing, nest sanitation, and nest fumigation (López-Rull and Macías Garcia 2015; West et al. 2015).

Nest fumigation involves incorporating fresh green plant fragments that contain ectoparasite-repellant volatile compounds and has been described in the nests of raptors, starlings (Sturnus sp.), sparrows (Passer domesticus), and blue tits (Bańbura et al. 1995; Lambrechts and Dos Santos 2000; Mennerat et al. 2009a, b; Dubiec et al. 2013). Plant species selected by those birds may function as a parasite repellent or an antimicrobial agent, and very often represent a non-random and small fraction of all species available in the breeding habitat (Pires et al. 2012). Petit et al. (2002) found that of over 200 identified species available in their study area, only 6 or 10 species (depending on the breeding season) were brought to the nests of blue tits. Some female blue tits actively incorporated fresh plant fragments to the lining layer sometimes even daily (Petit et al. 2002). Among plant species that are found in some of blue tit nests are Lavandula sp., Achillea sp., Mentha suaveolens, Helichrysum italicum, Dittrichia viscosa, Melissa officinalis, Clinopodium nepeta, Veronica sp., or Galeobdolon luteum (Petit et al. 2002; Mennerat et al. 2009a, b; Pires et al. 2012; Dubiec et al. 2013; MGl unpublished data and personal observations). Some of the listed plants are not native to Poland, but more typical of the Mediterranean basin. British blue tits often use Glechoma hederacea and Lamium purpurium within their nests (Stenning 2018).

Dubiec et al. (2013) reviews this topic and concludes by stating that our knowledge on the effects and functions of incorporating fresh green, aromatic plant material into avian nests (and its impact on nestlings) is, at present, rather fragmentary and incomplete. We are aware of only a few experimental papers using blue tits as subjects, including Petit et al. (2002), Mennerat et al. (2008, 2009a, b), and Tomás et al. (2012). In addition, Dubiec et al. (2013) add that the impact of fresh green material on nestling physiological traits should be investigated and further studies are needed to fully understand this behavior and its effects.

Hematological parameters are considered indicators of body physiological condition and are frequently used in experimental and field studies of mammals and birds (Kaliński et al. 2009; Johnstone et al. 2015; Minias 2015; Podlaszczuk et al. 2017; Glądalski et al. 2019). In general, changes in hemoglobin concentration may be caused by various factors, such as nutritional deficiency, hydration, sex, energy expenditure, or age (Stevens 1996). Our long-term studies on great tits and blue tits in Poland suggest that the concentration of hemoglobin is positively related to good physiological (body) condition of nestlings (Kaliński et al. 2015, 2016, 2017; Glądalski et al. 2016b, 2018).

The level of blood glucose is considered a reverse (lower concentration of glucose is related to higher body condition) and a less robust (more variable) indicator of body condition than hemoglobin but is also useful in studies of ecophysiology (Lill 2011; Minias and Kaczmarek 2013; Glądalski et al. 2015a, 2018). Blood glucose level is considered mainly to reflect metabolic rates of birds and mammals (Brown 1996). Our data on the great tit and blue tit populations suggest that glucose concentration is negatively related to body condition of nestlings (Kaliński et al. 2014, 2016; Glądalski et al. 2018).

In the present study, we test if the experimental supplementation of fresh, aromatic plants into the nest affects body condition and therefore fitness of the blue tit nestlings. We use the levels of hemoglobin $(\mathrm{g} / \mathrm{l})$ and glucose $(\mathrm{mg} / \mathrm{dl})$ in the blood of 13-day-old nestlings as biochemical indicators of nestling body condition. Our hypothesis is that nestlings from nests with added fresh, green, aromatic plants should improve the health status (higher mean hemoglobin concentration and lower mean glucose concentration) in comparison with nestlings from control nests.

\section{Materials and methods}

\section{Study areas}

The present study, carried out in 2019, is a part of a long-term project of research on the breeding biology of secondary cavity nesters in Łódź, Poland (Glądalski et al. 2015b). The study sites are located in two floristically and structurally contrasting types of habitats, $10 \mathrm{~km}$ apart. The forest study area $\left(51^{\circ} 50^{\prime} \mathrm{N}\right.$, $19^{\circ} 29^{\prime} \mathrm{E}$ ), about 145 ha area in the center of a mature mixed 
deciduous forest (about 1250 ha in total), with oaks as the prevailing tree species, is located in the northeast part of the city of Łódź. The urban parkland study area $\left(51^{\circ} 45^{\prime} \mathrm{N} ; 19^{\circ} 24^{\prime}\right.$ E), about 80 ha, located in the western part of the city of Łódź, has a fragmented tree cover (formed artificially) with hornbeams (Carpinus betulus), birches (Betula sp.) oaks (Quercus robur and $Q$. petraea), some small patches artificially wooded with scots pines (Pinus silvestris) and some exotic tree species. The study sites were visited every day during the breeding season (April-May) to record the number of nestlings and nestling age. The study sites were supplied with approximately 500 standard wooden nestboxes with removable front wall and with internal dimensions of 11.5 (depth) $\times 11$ (width) $\times 30$ (height) $\mathrm{cm}$ and a $3-\mathrm{cm}$-diameter entrance located $20 \mathrm{~cm}$ from the bottom of the nestbox (Lambrechts et al. 2010); there were about 300 nestboxes in the forest area and about 200 in the urban parkland area. All nestboxes were cleaned out prior to the breeding season.

\section{Field and experimental procedures}

Of 33 completely incubated blue tit clutches without fresh plant material supplemented by birds on their own, 17 were randomly assigned to the experimental treatment ( 9 in the parkland and 8 in the forest) and 16 were control broods ( 8 in the parkland and 8 in the forest). In 2019, we recorded three nests of blue tits with fresh, aromatic plant fragments. Nests supplemented with fresh plants by parental birds were excluded from the experimental treatment before the experiment started. The mean numbers of blue tit nestlings did not differ between control and treated nests $(8.25 \pm 1.88$ SD vs. $8.77 \pm$ 1.68 nestlings/nest; $t=0.83, d f=31, P=0.41)$ or between the parkland and the forest study areas $(8.64 \pm 1.97 \mathrm{SD}$ vs. $8.38 \pm$ 1.59 nestlings/nest; $t=0.44, d f=31, P=0.67$ ).

On days $3,5,7,9$, and 11 post-hatching, $1 \mathrm{~g}$ of fresh aromatic plants was added to treated nests and $1 \mathrm{~g}$ of fresh grass (Poaceae spp.) was supplemented in control nests. All the fresh plants were placed on the edge of the lining layer of the nest. A 1-g portion of aromatic plants consisted of approximately $0.33 \mathrm{~g}$ of lavender Lavandula angustifolia, about $0.33 \mathrm{~g}$ of the Common Yarrow Achillea millefolium, and about $0.33 \mathrm{~g}$ of the Immortelle Helichrysum italicum. All plants used in the experiment normally occur in the geographical distribution of the blue tit and are found in natural tit nests. All the plant species used were bought in a specialized gardening store in pots a week prior to the experiment. Every morning before going to the study sites, fresh leaves were cut off the plants and put in small plastic bags (one portion of each plant species was weighed for every nestbox). Plant clippings were placed in all the experimental nestboxes within $2 \mathrm{~h}$. At our study areas, the plants we added were not available in the general habitat, nor were they ever found in the nests; nevertheless, the birds kept the added plant material in their nests and never removed it. It was not possible to record data blind because our study involved focal animals in the field.

\section{Physiological measurements}

When the nestlings were 13 days old, they were banded with metal rings. As a random subsample, three nestlings of the same age from each brood were designated for blood sampling (Kaliński et al. 2015, 2016). Blood samples of ca. $5 \mu \mathrm{l}$ were taken from the ulnar vain of nestlings (98 nestlings from 33 clutches) to HemoCue cuvettes and analyzed immediately using portable HemoCue Hb 201+ photometer (HemoCue AB, Angelholm, Sweden) to measure hemoglobin concentration $(\mathrm{g} / \mathrm{l})$. To establish glucose concentration $(\mathrm{mg} / \mathrm{dl})$ in a second blood sample $(5 \mu \mathrm{l})$, a portable HemoCue Glucose 201+ photometer was used ( 99 nestlings from 33 clutches). All field procedures were performed between 09:00 and 14:00 h.

\section{Statistical analyses}

Values of glucose and hemoglobin concentration in the blood of nestlings from the same brood were not independent. Therefore, individual nestling values (which were as unit records) were analyzed with mixed linear models using brood ID being included as a random effect (to control for clustering) and degrees of freedom were approximated by the Satterthwaite method (Heck et al. 2010). Experimental treatment and study site were treated as fixed factors in these models. Non-significant interactions were removed. Linear mixed modeling was conducted using IBM SPSS Statistics 22 software (Heck et al. 2010, 2012; IBM SPSS Statistics 22 2013).

\section{Data availability}

The datasets generated and/or analyzed during the current study are available from the corresponding author on reasonable request.

\section{Results}

A total of 33 broods of the blue tit were included in this study (99 nestlings were bled). Per-nest mean concentrations of hemoglobin ranged from $103.3 \mathrm{~g} / 1$ to $140.7 \mathrm{~g} / \mathrm{l}$. The nestlings from the treated nests had a significantly higher hemoglobin level (on average $7.9 \mathrm{~g} / \mathrm{l}$ higher) than the nestlings from the control nests (Table 1, Fig. 1). The mean hemoglobin level did not vary between study sites (Table 1).

Per-nest mean concentrations of glucose varied in the parkland study area from $180.33 \mathrm{mg} / \mathrm{dl}$ to $263.3 \mathrm{mg} / \mathrm{dl}$ and in the forest study area from $213.6 \mathrm{mg} / \mathrm{dl}$ to $339.0 \mathrm{mg} / \mathrm{dl}$. The nestlings from the parkland study area had significantly lower 
glucose concentration (on average $47.0 \mathrm{mg} / \mathrm{dl}$ lower) than the nestlings from the forest study area (Table 1, Fig. 1). The level of glucose between the nestlings from the control and the treated nests did not differ (Table 1).

\section{Discussion}

In this study, we found that nestlings of blue tits in nests supplemented with aromatic plants had increased levels of hemoglobin when compared to control nests and there was no difference in hemoglobin concentration between study areas. The less robust body condition indicator - the level of glucose- did not differ between supplemented and control nests, but it differed between study areas. The nestlings from the parkland site had on average lower concentration of glucose.

All three plant species used in the present experiment are characterized by a repellent effect on the insects (Achillea millefolium, De Almeida et al. 2017; Lavandula angustifolia, Germinara et al. 2017), antifungal (Lavandula angustifolia, Adam et al. 1998), antimicrobial, and antiinflammatory properties (Helichrysum italicum, Viegas et al. 2014). Mennerat et al. (2008) reported that nestlings in nests containing supplemented aromatic plants had higher hematocrit levels and their feathers developed faster, but there were no significant effects on chick body size at fledging. Tomás et al. (2012) in their experiment on blue tits with aromatic plants found no effect on hatching or fledging success, nestling body mass, or female body condition. Tomás et al. (2012) and Mennerat et al. (2008, 2009a, b) emphasize that they removed all detectable fresh, green material placed in experimental nests by blue tit females; however, when green

Table 1 Summary of a linear mixed model analysis for hemoglobin and glucose concentrations in the blood of the blue tit nestlings

\begin{tabular}{lrrr}
\hline Factor & $d f$ & \multicolumn{1}{l}{$F$} & \multicolumn{1}{l}{$P$} \\
\hline Hemoglobin & & & \\
Intercept & $1 ; 30.1$ & 5132.3 & $<\mathbf{0 . 0 0 1}$ \\
Study area & $1 ; 30.0$ & 2.0 & 0.165 \\
Experiment & $1 ; 30.0$ & 5.6 & $\mathbf{0 . 0 2 4}$ \\
Removed non-significant effects & & & \\
Study area $\times$ experiment & $1 ; 29.1$ & 0.1 & 0.792 \\
Glucose & & & \\
Intercept & $1 ; 30.0$ & 1626.2 & $<\mathbf{0 . 0 0 1}$ \\
Study area & $1 ; 30.0$ & 15.0 & $\mathbf{0 . 0 0 1}$ \\
Experiment & $1 ; 30.0$ & 1.6 & 0.222 \\
Removed non-significant effects & & & \\
Study area $\times$ experiment & $1 ; 29.0$ & 3.9 & 0.059 \\
\hline
\end{tabular}

Effects of study area and experimental treatment are given. Nonsignificant effects were removed. Significant values are in bold material is experimentally removed in control nests, females may rapidly add new fresh plant fragments to the nests. In this study, less than $10 \%$ of nests were supplemented by birds with fresh plants; those nests were excluded from the experimental treatment. Additionally, condition indicators (and breeding success) may be incapable of detecting more subtle physiological changes in a single year.

Słomczyński et al. (2006) replaced all natural nests with artificial, sterile nests, reducing parasitic and pathogenic pressure on blue tit nestlings. The experimental treatment showed that nestlings from artificial nests improved their health and had on average 7-10 g/l higher level of hemoglobin than control nestlings. This suggests that the experimental effect of reduction of parasite pressure (and improving body condition of nestlings) is analogous when comparing sterile nest experiment to fresh plant repellents in the present experiment
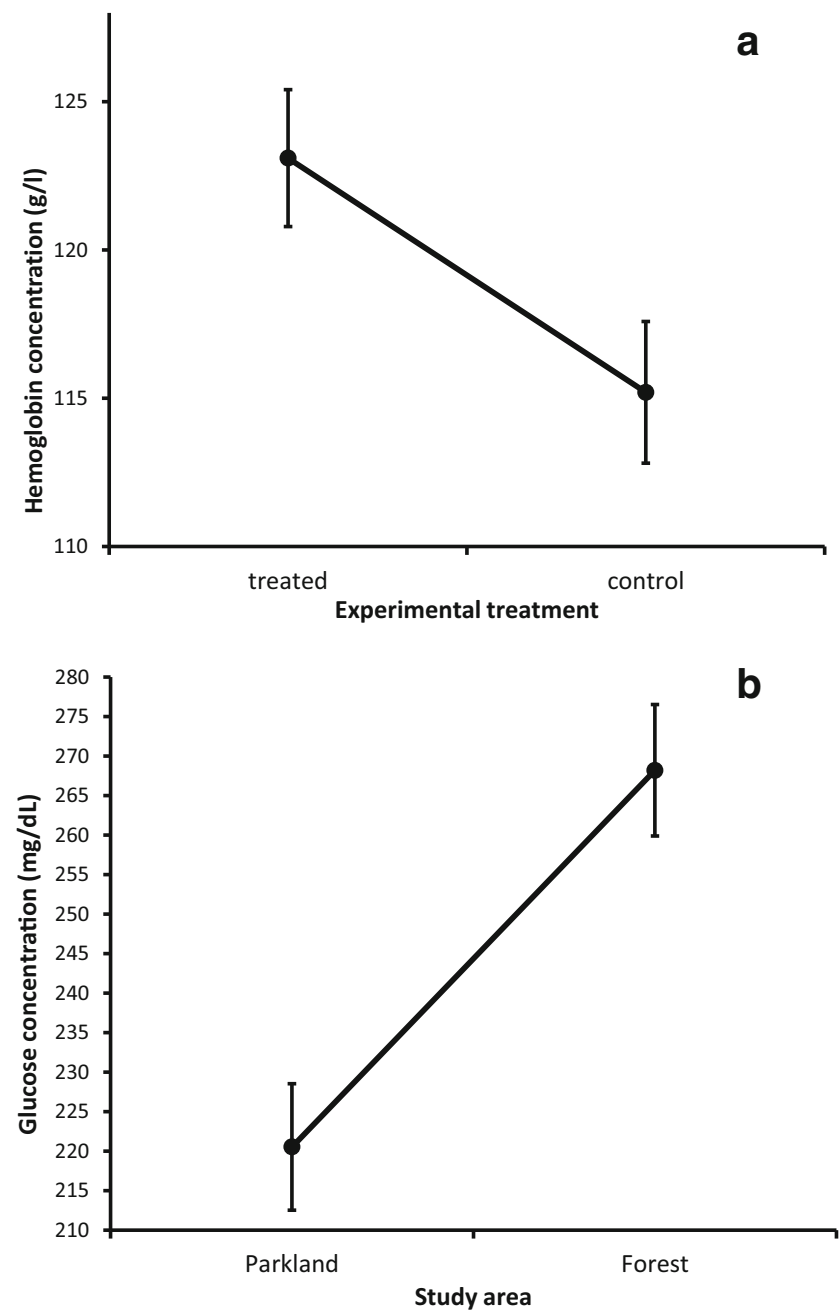

Fig. 1 a Mean hemoglobin concentration $(\mathrm{g} / \mathrm{l})$ in the blood of the blue tit nestlings in experimentally treated nests with aromatic plants added $(123.1 \pm 2.3 \mathrm{~g} / \mathrm{l})$ and control nests $(115.2 \pm 2.4 \mathrm{~g} / \mathrm{l})$. b Mean glucose concentration $(\mathrm{mg} / \mathrm{dl})$ in the blood of the blue tit nestlings in the parkland study area $(221.2 \pm 10.4 \mathrm{mg} / \mathrm{dl})$ and in the forest study area $(268.2 \pm 10.6 \mathrm{mg} / \mathrm{dl})$. Data are shown as mean $\pm \mathrm{SE}$ 
(mean 7-10 g/l vs. mean $7.9 \mathrm{~g} / 1$ ). In general, our present and previous (Słomczyński et al. 2006; Glądalski et al. 2018) experiments suggest that the level of hemoglobin in nestlings is a robust body condition indicator and may detect also subtle changes in condition like changes in ectoparasite pressure on nestlings.

In our previous research on both blue tits and great tits (Kaliński et al. 2014, 2016), we showed that mean glucose concentrations in nestling blood differed between parkland and forest study areas, with the value for the urban parkland site being often (but not always) higher than the value for the forest site. However, there was significant annual variation in glucose levels. Kaliński et al. (2014) suggest that in years when there are lower temperatures in the spring, mean glucose concentrations in nestling birds will be higher. In addition, parkland and forest habitats used in this study differed in caterpillar productivity. In other years, productivity in the forest was 2-5 times higher than in the parkland (Glądalski et al. 2015b; Kaliński et al. 2015); whereas in 2019, the difference was only marginal. However, causal relations between glucose concentrations and environmental variables are complex and generally unclear; therefore, they require further investigation. It is also important to emphasize that birds from the forest may be more stressed when it comes to human presence than urban birds. Therefore, frequent exposure to human visitors (experimental procedures) could disturb to a larger degree the regularity of feeding nestlings by parents in the forest than in the urban parkland (Ruiz et al. 2002).

Blue tits vary considerably across their Western Palearctic range, particularly, in their behavior, including hygienic behavior (Mainwaring 2016, 2017). Blue tits occur from North Africa to Arctic Norway and the plants available to them will vary accordingly. Climate also plays a part because parasite numbers and diversity decrease with distance from the equator (Lindenfors et al. 2007); therefore, selection on poikilothermic parasite control behavior may be a significant factor in the natural selection of hygienic behavior.

The present study confirms that the behavior of adding aromatic, fresh plants by blue tits into their nests may have positive impact on nestlings' body condition and therefore on fitness. Present study confirms that the concentration of hemoglobin is a reliable and robust indicator of environmental pressures in blue tits. On the other hand, our study confirms that the level of glucose is a less robust indicator of parasite pressure and it may not detect more subtle changes and should rather be used as a complementary indicator of parasite pressure. The level of glucose may be more useful as indicator of habitat conditions. We agree with Dubiec et al. (2013) that our knowledge on the effects (and especially physiological effects) of incorporating fresh green, aromatic plant material into avian nests is still rather fragmentary and incomplete. The behavior of adding aromatic, fresh plants may be also locally and genetically specific, so there is a need to study this phenomenon at a broader scale. More experimental studies that are using properly sensitive physiological indicators such as the level of hemoglobin are needed.

Acknowledgments We thank A. Jaksa, M. Winsche, D. Mańkowska, and J. Białek for their help and consent to conducting research in the areas under their administration. We would like to thank Beata Woziwoda and Anna Bomanowska for botanical consultation. We are very grateful to two anonymous referees and the associate editor for critical comments and constructive suggestions on the previous draft of the manuscript. We thank A. Cowie for linguistic consultation.

Funding information This research was supported by the University of Łódź (No. 506/1145).

\section{Compliance with ethical standards}

Conflict of interest The authors declare that they have no conflict of interest.

Ethical approval All applicable international, national, and institutional guidelines for the use of animals were followed. All procedures were approved by the Local Ethical Committee nr. 70/LB07/2015 and the State Office for Environment Protection WPN-II.6401.13.2016.

Ethical statement This manuscript is all original work, has not been published previously (partially or in full). No data in this manuscript have been fabricated or manipulated, and all authors have given consent to submit this manuscript and have contributed sufficiently to the scientific work.

Open Access This article is licensed under a Creative Commons Attribution 4.0 International License, which permits use, sharing, adaptation, distribution and reproduction in any medium or format, as long as you give appropriate credit to the original author(s) and the source, provide a link to the Creative Commons licence, and indicate if changes were made. The images or other third party material in this article are included in the article's Creative Commons licence, unless indicated otherwise in a credit line to the material. If material is not included in the article's Creative Commons licence and your intended use is not permitted by statutory regulation or exceeds the permitted use, you will need to obtain permission directly from the copyright holder. To view a copy of this licence, visit http://creativecommons.org/licenses/by/4.0/.

\section{References}

Adam K, Sivropoulou A, Kokkini S, Lanaras T, Arsenakis M (1998) Antifungal activities of Origanum vulgare subsp. Hirtum, Mentha spicata, Lavandula angustifolia, and Salvia fruticosa essential oils against human pathogenic fungi. J Agric Food Chem 46:1739-1745

Álvarez E, Belda EJ, Verdejo J, Barba E (2013) Variation in great tit nest mass and composition and its breeding consequences: a comparative study in four Mediterranean habitats. Avian Biol Res 6:39-46

Bańbura J, Blondel J, de Wilde-Lambrechts H, Perret P (1995) Why do female blue tits (Parus caeruleus) bring fresh plants to their nests? J Ornithol 136:217-221

Bańbura J, Perret P, Blondel J, Sauvages A, Galan M-J, Lambrechts M (2001) Sex differences in parental care in a Corsican blue tit Parus caeruleus population. Ardea 89:17-526 
Brown ME (1996) Assessing body condition in birds. Curr Ornithol 13: $67-135$

Collias NE, Collias EC (1984) Nest building and bird behaviour. Princeton University Press, Princeton

De Almeida J, Cormier D, Lucas E (2017) Effect of Achillea millefolium strips and essential oil on the European apple sawfly, Hoplocampa testudinea (Hymenoptera: Tenthredinidea). Entomol Ornithol Herpetol 6:3

Deeming DC (2011) Importance of nest type on the regulation of humidity in bird nests. Avian Biol Res 4:23-31

Deeming DC, Campion E (2018) Simulated rainfall reduces the insulative properties of bird nests. Acta Ornithol 53:91-97

Deeming DC, Morton FEM, Laverack KL (2019) Nestbox size affects mass and proportions of materials used in blue tit Cyanistes caeruleus nests. Bird Study (published online. https://doi.org/10. 1080/00063657.2019.1618243

Dubiec A, Góźdź I, Mazgajski TD (2013) Green plant material in avian nests. Avian Biol Res 6:133-146

Germinara GS, Distefano MG, Acutis LD, Pati S, Delfne S, Cristofaro AD, Rotundo G (2017) Bioactivities of Lavandula angustifolia essential oil against the stored grain pest Sitophilus granaries. Bull Insect 70:129-138

Glądalski M, Skwarska J, Kaliński A, Bańbura M, Markowski M, Wawrzyniak J, Zieliński P, Bańbura J (2015a) Patterns of year-toyear variation in haemoglobin and glucose concentrations in the blood of nestling pied flycatchers, Ficedula hypoleuca. J Ornithol 156:811-817

Glądalski M, Bańbura M, Kaliński A, Markowski M, Skwarska J, Wawrzyniak J, Zieliński P, Cyżewska I, Bańbura J (2015b) Interannual and inter-habitat variation in breeding performance of blue tits (Cyanistes caeruleus) in Central Poland. Ornis Fenn 92:34-42

Glądalski M, Bańbura M, Kaliński A, Markowski M, Skwarska J, Wawrzyniak J, Zieliński P, Cyżewska I, Bańbura J (2016a) Effects of nest characteristics on reproductive performance in blue tits Cyanistes caeruleus and great tits Parus major. Avian Biol Res 9: $37-43$

Glądalski M, Bańbura M, Kaliński A, Markowski M, Skwarska J, Wawrzyniak J, Zieliński P, Bańbura J (2016b) Spatial variation in haemoglobin concentration of nestling blue tits (Cyanistes caeruleus): a long-term perspective. J Ornithol 157:591-598

Glądalski M, Kaliński A, Wawrzyniak J, Bańbura M, Markowski M, Skwarska J, Bańbura J (2018) Physiological condition of nestling great tits Parus major in response to experimental reduction in nest micro- and macro-parasites. Conserv Physiol 6:coy062

Glądalski M, Cyżewska I, Bańbura M, Kaliński A, Markowski M, Skwarska J, Wawrzyniak J, Bańbura J (2019) Influence of habitat composition on nestling body condition and breeding success in European pied flycatchers (Ficedula hypoleuca). Avian Biol Res (published online. https://doi.org/10.1177/1758155919834466

Goodenough AE, Stallwood B (2010) Intraspecific variation and interspecific differences in the bacterial and fungal assemblages of blue tit (Cyanistes caeruleus) and great tit (Parus major) nests. Microb Ecol 59:221-232

Hamilton W, Zuk M (1982) Heritable true fitness and bright birds: a role for parasites? Science 218:384-387

Heck RH, Thomas SL, Tabata LN (2010) Multilevel and longitudinal modelling with IBM SPSS. Routledge, New York

Heck RH, Thomas SL, Tabata LN (2012) Multilevel modeling of categorical outcomes using IBM SPSS. Routledge, New York

Heenan CB (2013) An overview of the factors influencing the morphology and thermal properties of avian nests. Avian Biol Res 6:104118

Heylen D, Adriaensen F, Van Dongen S, Sprong H, Matthysen E (2013) Ecological factors that determine Ixodes ricinus tick burdens in the great tit (Parus major), an avian reservoir of Borrelia burgdorferi. Int J Parasitol 43:603-611
Hurtrez-Boussès S, Blondel J, Perret P, Fabreguettes J, Renaud F (1998) Chick parasitism by blowflies affects feeding rates in a Mediterranean population of blue tits. Ecol Lett 1:17-20

IBM SPSS Statistics 22 (2013) SPSS for Windows Release 22.0. IBM Corporation, Armonk

Johnstone CP, Lill A, Reina RD (2015) Use of erythrocyte indicators of health and condition in vertebrate ecophysiology: a review and appraisal. Biol Rev 92:150-168

Kaliński A, Wawrzyniak J, Bańbura M, Skwarska J, Zieliński P, Bańbura J (2009) Haemoglobin concentration and body conditions of nestling great tits Parus major: a comparison of first and second broods in two contrasting seasons. Ibis 151:667-676

Kaliński A, Bańbura M, Glądalski M, Markowski M, Skwarska J, Wawrzyniak J, Zieliński P, Cyżewska I, Bańbura J (2014) Landscape patterns of variation in blood glucose concentration of nestling blue tits (Cyanistes caeruleus). Landsc Ecol 29:1521-1530

Kaliński A, Bańbura M, Glądalski M, Markowski M, Skwarska J, Wawrzyniak J, Zieliński P, Cyżewska I, Bańbura J (2015) Longterm variation in haemoglobin concentration in nestling great tits Parus major. Comp Biochem Physiol A 185:9-15

Kaliński A, Bańbura M, Glądalski M, Markowski M, Skwarska J, Wawrzyniak J, Zieliński P, Cyżewska I, Bańbura J (2016) Relationship between blood haemoglobin and glucose concentrations in adult great tits (Parus major) and blue tits (Cyanistes caeruleus). Avian Biol Res 9:152-158

Kaliński A, Bańbura M, Glądalski M, Markowski M, Skwarska J, Wawrzyniak J, Zieliński P, Bańbura J (2017) Nestling physiological performance in great tits Parus major and blue tits Cyanistes caeruleus in relation to brood fledging success. Acta Ornithol 52: $141-148$

Lambrechts MM, Dos Santos A (2000) Aromatic herbs in Corsican blue tit nests: the 'potpourri' hypothesis. Acta Oecol 21:175-178

Lambrechts MM, Adriaensen F, Ardia DR et al (2010) The design of artificial nestboxes for the study of secondary hole-nesting birds: a review of methodological inconsistencies and potential biases. Acta Ornithol 45:1-26

Lambrechts MM, Demeyrier V, Fargevieille A et al (2014) Great tits build shallower nests than blue tits. Avian Biol Res 7:251-254

Lambrechts MM, Blondel J, de Franceschi C, Doutrelant C (2017) Nest size is positively correlated with fledging success in Corsican blue tits (Cyanistes caeruleus) in an insular oak-dominated habitat mosaic. J Ornithol 158:125-132

Lill A (2011) Sources of variation in blood glucose concentrations of freeliving birds. Avian Biol Res 4:78-86

Lindenfors P, Nunn CL, Jones KE, Cunningham AA, Sechrest W, Gittleman JL (2007) Parasite species richness in carnivores: effects of host body mass, latitude, geographic range and population density. Glob Ecol Biogeogr 16:496-509

López-Rull I, Macías Garcia C (2015) Control of invertebrate occupants of nests. In: Deeming DC, Reynolds SJ (eds) Nests, eggs and incubation: new ideas about avian reproduction. Oxford University Press, Oxford, pp 82-96

Mainwaring MC (2016) The transition from dependence to independence in birds. Behav Ecol Sociobiol 70:1419-1431

Mainwaring MC (2017) Causes and consequences of intraspecific variation in nesting behaviors: insights from blue tits and great tits. Front Ecol Evol 5:39

Mainwaring MC, Hartley IR, Lambrechts MM, Deeming DC (2014) The design and function of birds' nests. Ecol Evol 20:3909-3928

Maziarz M, Broughton RK, Wesołowski T (2017) Microclimate in tree cavities and nest-boxes: implications for hole-nesting birds. Forest Ecol Manag 389:306-313

Mennerat A, Perret P, Caro SP, Heeb P, Lambrechts MM (2008) Aromatic plants in blue tit Cyanistes caeruleus nests: no negative effect on blood-sucking Protocalliphora blow fly larvae. J Avian Biol 39: 127-132 
Mennerat A, Mirleau P, Blondel J, Perret P, Lambrechts MM, Heeb P (2009a) Aromatic plants in nests of the blue tit Cyanistes caeruleus protect chicks from bacteria. Oecologia 161:849-855

Mennerat A, Perret P, Bourgault P, Blondel J, Gimenez O, Thomas WD, Heeb P, Lambrechts MM (2009b) Aromatic plants in nests of blue tits: positive effects on nestlings. Anim Behav 77:569-574

Minias P (2015) The use of haemoglobin concentrations to assess physiological condition in birds: a review. Conserv Physiol 3:cov007

Minias P, Kaczmarek K (2013) Concentrations of plasma metabolites as predictors of nestling condition in the great cormorant (Phalacrocorax carbo sinensis). Ornis Fenn 90:142-150

Petit C, Hossaert-McKey M, Perret P, Blondel J, Lambrechts MM (2002) Blue tits use selected plants and olfaction to maintain an aromatic environment for nestlings. Ecol Lett 5:585-589

Pires AB, Belo FA, Rabaça EJ (2012) Aromatic plants in Eurasia blue tit nests: the 'nest protection hypothesis' revisited. Wilson J Ornithol 124:162-165

Podlaszczuk P, Włodarczyk R, Janiszewski T, Kaczmarek K, Minias P (2017) When moult overlaps migration: moult-related changes in plasma biochemistry of migrating common snipe. PeerJ 5:e3057

Reynolds SJ, Davies CS, Elwell E, Tasker PJ, Williams A, Sadler P, Hunt D (2016) Does the urban gradient influence the composition and ectoparasite load of nests of an urban bird species? Avian Biol Res 9:224-234
Ruiz G, Rosenmann M, Novoa FF, Sabat P (2002) Hematological parameters and stress index in rufous-collared sparrows dwelling in urban environments. Condor 104:162-166

Słomczyński R, Kaliński A, Wawrzyniak J, Bańbura M, Skwarska J, Zieliński P, Bańbura J (2006) Effects of experimental reduction in nest micro-parasite and macro-parasite loads on nestling hemoglobin level in blue tits Parus caeruleus. Acta Oecol 30:223-227

Stenning M (2018) The blue tit. T \& AD Poyser, London

Stevens L (1996) Avian biochemistry and molecular biology. Cambridge University Press, Cambridge

Tomás G, Merino S, Martínez-de la Puente J, Moreno J, Morales J, Lobato E, Rivero-de Aguilar J, del Cerro S (2012) Interacting effects of aromatic plants and female age on nest-dwelling ectoparasites and blood-sucking flies in avian nests. Behav Process 90:246-253

Viegas DA, Palmeira-de-Oliveira A, Salgueiro L, Martinez-de-Oliveira J, Palmeira-de-Oliveira R (2014) Helichrysum italicum: from traditional use to scientific data. J Ethnopharmacol 151:54-65

West A, Cassey P, Thomas CM (2015) Microbiology of nests and eggs. In: Deeming DC, Reynolds SJ (eds) Nests, eggs and incubation: new ideas about avian reproduction. Oxford University Press, Oxford, pp 82-96

Publisher's note Springer Nature remains neutral with regard to jurisdictional claims in published maps and institutional affiliations. 